\title{
ESBOÇO DE UMA POLÍTICA COMUNICACIONAL E EXPOSIÇÃO DE UMA MATRIZ DISCURSIVA: A PRIMEIRA VEICULAÇÃO DE ALÓ PRESIDENTE (HUGO CHÁVEZ, 1999)
}

\section{Elvira Narvaja de Arnoux ${ }^{\mathrm{i}}$}

Resumo: Hugo Chávez, presidente da Venezuela entre 1999 e 2013, insistentemente apelou à mídia para convocar e mobilizar a população. Aló Presidente, que foi primeiro uma transmissão de rádio e depois uma transmissão televisiva, desempenhou um papel importante no desenvolvimento da "Revolução Bolivariana". Neste artigo, analisamos o início da série. Abordamos a relação que o formato do programa habilita entre o midiático e o político e analisaremos, por um lado, o dispositivo enunciativo no qual a dimensão emocional tem um peso significativo e, por outro, os objetos que voltam insistentemente: a Constituinte, a relação de pessoas e exército, aquilo a que se opõe a revolução bolivariana e as afiliações a que se refere. Consideramos que tanto o dispositivo enunciativo quanto os modos de construir objetos formam a matriz de uma discursividade que se desdobrará ao longo da vida política de Chávez.

Palavras-chave: Hugo Chavez. Matriz discursiva. Dispositivo enunciativo. Política de comunicação.

\begin{abstract}
Hugo Chávez, president of Venezuela from 1999 to 2013, insistently resorted to the media to rally and mobilize the population. Aló Presidente, which was first broadcast on radio and later on television, played an important part in the development of the "Bolivarian revolution". In this article we shall look at the broadcast that began the series. We shall explore the relationship enabled by its format between the media and politics by analyzing on the one hand, the enunciative device, in which the emotional dimension is important, and on the other hand, the objects returned to insistently: the Constituent Assembly, the people-army relationship, what the Bolivarian revolution opposes, and what affiliations it relies on. We consider that both the enunciative device and the ways of constructing the objects establish the matrix of the discourse that was to unfold throughout Chávez's political life.
\end{abstract}

Keywords: Hugo Chávez. Discursive matrix. Enunciative device. Communication policies.

\footnotetext{
' Docente do Instituto de Linguística da Faculdade de Filosofia e Letras da Universidade de Buenos Aires (UBA), Argentina. Email: elviraarnoux@gmail.com.
} 
EID\&A - Revista Eletrônica de Estudos Integrados em Discurso e Argumentação, Ilhéus, n. 16 esp. "Discurso e argumentação na política latino-americana, set.2018.

\section{Introdução}

Em 9 de dezembro de 2012, depois do triunfo eleitoral, em coletiva de imprensa com a presença de mídias nacionais e estrangeiras ${ }^{1}$, Hugo Chávez se refere às novas formas de campanha política a partir do artigo de uma jornalista brasileira que fala de "assédio eleitoral" contando sua experiência em Caracas, ocasião em que recebeu milhares de chamadas telefônicas via mensagem de texto enviadas em apoio a Capriles. Chávez aponta que "foram 500 mil ligações em uma noite, partindo da Europa e da América do Norte" nas quais robôs intervinham com mensagens gravadas. Acrescenta que, para a jornalista, Capriles conta "com o apoio de grandes empresas multinacionais pelo custo que isso implica". Opõe tal situação a outro tipo de campanha:

Nós nunca fizemos nada disso, não fizemos nada além de uma campanha tradicional, do mais tradicional estilo de campanha, propaganda, as turnês, o candidato, as entrevistas. Não há dúvida de que eles utilizaram distintos níveis e tipos de campanha e muitos muitos recursos, ora.

E assinala que adverte Correa a respeito de que tem que se formar "equipes para avaliar estas novas formas de guerra, de batalha eleitoral". Estas novas formas - com a capacidade de expansão que as novas tecnologias asseguram e o tipo de mensagem contínua, personalizada e frequentemente eufórica, em que, insistentemente, fazem do destinatário partícipe das conquistas do futuro dadas como certas e da importância de sua intervenção para alcançá-los - combatem os modos tradicionais da política e em muitos casos resultam vitoriosas.

Chávez ganhou sua última batalha eleitoral, e as anteriores, apelando aos dispositivos "tradicionais", particularmente os midiáticos (imprensa, rádio, televisão), de cuja importância foi consciente desde o começo de sua vida política (desde sua rendição em 1992, quando a televisão torna massivamente pública sua figura) explorando muitas de suas potencialidades e modelando inclusive seu discurso político às exigências de cada meio e à necessidade de chegar de forma contínua a uma audiência ampla. A conversa, com as diversas formas de proximidade que permite, com a diversidade de cenografias que admite e os papéis variados que o locutor pode assumir, estendeu-se na esfera pública midiática a serviço dos objetivos políticos da revolução bolivariana.

\footnotetext{
${ }^{1}$ Nesta, como nas outras referências às palavras de Chávez, ver Todo Chávez (2016).
} 
EID\&A - Revista Eletrônica de Estudos Integrados em Discurso e Argumentação, Ilhéus, n. 16 esp. "Discurso e argumentação na política latino-americana, set.2018.

Para que esta conversa avançasse e se sustentasse era necessário, por um lado, construir novas identidades nacionais em cujos imaginários se articulasse a Pátria Grande, como futuro horizonte de referência, e o território próprio com suas diversidades sociais, geográficas, étnicas. Devia-se também atribuir aos setores populares o papel de motor consciente das transformações que deviam ser operadas para o qual as instâncias de formação, para levá-las a cabo, e de valorização do realizado, para manter o esforço entusiasta, eram incontornáveis. Do mesmo modo, devia-se mostrar a função social do exército nas novas tarefas que a revolução lhe dava e assegurar a relação exército / povo considerados os dois pilares do processo em marcha. Por outro lado, devia-se avaliar e controlar o cumprimento das tarefas para o qual a visibilidade de todos os atores comprometidos, entre eles os funcionários e os que realizavam tarefas de gestão a distintos níveis, era imprescindível.

Chávez interveio pessoalmente no núcleo duro da política comunicacional de governo adaptando-a aos distintos momentos do processo, o que implicava acentuar um ou outro aspecto, e a sua situação pessoal, que o levavam a derivar algumas das funções ou a acentuar a participação dos outros. Como ferramentas (surgidas em diferentes momentos e que, na maioria dos casos, têm coexistido) nas quais estava pessoalmente envolvido, ou seja, nas quais ele era o ator central ou estava na origem do dispositivo, podemos destacar Aló Presidente, sua conta pessoal na rede social Twitter, as reuniões com ministros e funcionários televisionadas, as cadeias de transmissão oficiais, as entrevistas e conferências de imprensa e as "linhas de Chávez", notas de opinião na imprensa. A estas se acrescentam a inauguração de Telesur, um dos empreendimentos mais notáveis de emissões internacionais, os portais digitais para as instituções públicas ou para os serviços públicos e as diversas participações nos meios dos funcionários.

Nos espaços interativos conversacionais que Chávez conduz, embora apareçam outras vozes com problemáticas específicas, existem certos núcleos aos que aquele volta com insistência e que vão construindo as representações de determinados objetos que se buscam impor ao auditório em cada ocasião. Esse retornar e retomar em uma mesma unidade de discurso desde diferentes lugares, para além de digressões, anedotas ou temas particulares relevados pelos ouvintes, mostra os eixos de seu discurso. Quando estas representações são estratégicas, ou seja, destinadas a desempenhar um papel significativo no 
EID\&A - Revista Eletrônica de Estudos Integrados em Discurso e Argumentação, Ilhéus, n. 16 esp. "Discurso e argumentação na política latino-americana, set.2018.

processo, reiteram-se em outras emissões com esquematizações variadas que expandem determinados aspectos, filtram outros ou operam acomodações diversas, ainda que mantenham o núcleo duro (como ocorre na construção do objeto discursivo "socialismo do século XXI", ARNOUX, 2013).

Neste artigo, nos deteremos na primeira emissão, via rádio, de Aló Presidente atendendo a sua condição de discurso que inicia uma série, abordando a relação que o formato habilita entre o midiático e o político e analisando, por um lado, o dispositivo enunciativo, no qual a dimensão emotiva tem um peso importante à medida que instaura um vínculo gerador de identificações que estimula a mobilização, e, por outro lado, os objetos aos que volta com insistência: a Constituinte, a relação de povo e exército, aquilo ao que se opõe a revolução bolivariana e as filiações a que remete. Consideramos que ambos, o dispositivo enunciativo e os modos de construir os objetos, ao fazer oposição ao outro e estabelecer filiações conformam a matriz de uma discursividade que se estenderá ao longo da vida política de Chávez, sustentados em uma trama ideológica persistente, apesar das mudanças no processo da revolução bolivariana.

\section{A abertura de Aló presidente: um discurso fundacional}

“Aló presidente" implicou um compromisso muito forte de Chávez, que se inicia em 23 de maio de 1999 e se encerra (n. 378) em 29 de janeiro de 2012, mais de seis meses depois de declarada sua doença. No início, tratava-se de uma transmissão via rádio e, a partir de um ano depois, passou a ser televisiva. Além disso, passou de uma hora a uma duração de aproximadamente cinco horas. Diversos autores destacam seus traços genéricos (em seu formato televisivo: BOLÍVAR, 2003; RAMÍREZ LASSO, 2012; ROSA GUALDA, 2012), sua capacidade de subverter o modelo hegemônico midiático da cultura do espectáculo e transformar a esfera pública de participação política (RAMíREZ LASSO, 2015), o domínio que expõe das estratégias discursivas, o que constitui a base do poder político de Chávez (BEAUGRANDE, 2008), a relação entre o desenvolvimento do projeto político e a transmissão televisiva (CONSTANTINI, 2014), as redes metafóricas em torno do "socialismo" (DUARTE, 2016), a dimensão afetiva e o uso de um "nós" pseudoinclusivo (NIETO Y OTERO, 2004), a forte proximidade que constrói a respeito do auditório próximo ideologicamente (ERLICH, 2005a) ou a distância frente ao oposto (ERLICH, 2005b), o ethos plebeu exposto multimodalmente (PEÑAFIEL, 2011). Trata-se 
EID\&A - Revista Eletrônica de Estudos Integrados em Discurso e Argumentação, Ilhéus, n. 16 esp. "Discurso e argumentação na política latino-americana, set.2018.

tanto da discursividade de Chávez como da discursividade dos participantes (RAMÍREZ LASSO, 2015). A metodologia é em geral qualitativa mas pode integrar dados relevados quantitativamente (GONZÁLEZ BINETTI, 2012) ou provenientes de operações próprias de uma linguística de corpus (SMITH, 2010).

De nossa parte, nos deteremos no esboço da audição, tal como se coloca na primeira emissão em que o formato midiático é remodelado e posto a serviço da política, contudo, ao mesmo tempo, é o espaço em que se estabelecem os novos modos de relação de governo (representado por seu presidente) com o povo (a que se interpela ainda que os destinatários primeiros sejam os ouvintes que participam e a audiência em geral) e se definem os eixos imediatos (de agenda) e mediatos (programáticos) da ação política. Nesse sentido, Aló Presidente pode ser visto, desde o ponto de vista do analista, como a metáfora midiática de um dispositivo político, mas também, se tratamos sobre o polo da produção, como a matriz midiática de um discorrer político. Se não o vemos nessa inter-relação entre o midiático e o político, podemos considerar que há uma "subversão da posição enunciativa esperada em um discurso presidencial" (PEÑAFIEL, 2011, p. 31). Na realidade, essa subversão, pensada como tal desde a perspectiva dos sistemas representativos habituais, é naturalizada pelo meio. Por outra parte, é aceita pelos seus seguidores porque se inscreve na legitimidade de uma memória discursiva nutrida pelos "modos de dizer" dos líderes nacionais e populares do continente nos quais predomina uma retórica da proximidade a que os modos midiáticos conversacionais se adaptam com facilidade.

A autoridade do locutor é tanto midiática (conduz o programa) como política (líder nacional e presidente) e a partir desse lugar habilita o tratamento e a valoração dos objetos dignos de chegar à esfera pública. Estenderá, além disso, a representação de si com os atributos que the permitem conduzir um processo revolucionário que se caracteriza por sua base popular. O ethos (AMOSSY, 2010; PLANTIN, 2016) será configurado a partir de diversas referências, entre outras, a sua vida passada, a seus gostos, a sua família, a seu compromisso político. Destacará, por um lado, aquilo que compartilha com os setores populares seja pela origem ou pelo contato assíduo ou pela sensibilidade. Isto lhe permitirá a proximidade com o outro, afirmada nos modos coloquiais de dizer e em estratégias variadas de aproximação assim como em formas de fazer visível, desde o recorte midiático 
EID\&A - Revista Eletrônica de Estudos Integrados em Discurso e Argumentação, Ilhéus, n. 16 esp. "Discurso e argumentação na política latino-americana, set.2018.

da audiência, ao povo da nação na heterogeneidade de suas posições e de suas demandas. Por outro lado, construirá a figura do revolucionário a partir do dizer verdadeiro (FOUCAULT, 2010), de um sujeto que se nega a aceitar o engano e a mentira. Daí a importância do tópico do ocultamento que permite diferenciar os que apoiam o caminho bolivariano dos que se opõem a ele.

O dispositivo enunciativo, no qual o vínculo que se ata é essencial, legitima e valoriza os objetos a que se refere e faz possíveis interpelações e convocatórias. Configura assim uma matriz de discursividade que define funções e papeis, salienta as possibilidades e os limites dos respectivos lugares e que vai construindo uma memória que atua como campo de referência para os interlocutores. O mesmo Chávez valoriza esta primeira emissão já que, ao festejar a número 100, transmite-a novamente (BOLÍVAR, 2003: 92).

As operações de voltar e retomar os objetos do discurso se ativam graças a sintagmas nominais que se reiteram (constituinte, Assembleia Constituinte) com variações dentro de um mesmo paradigma designativo (as Forças Armadas, meus companheiros de armas) que permitem a fixação do novo segmento na representação que já se havia aberto. $O$ tematizar outra vez o objeto (SITRI, 2003) a que se havia referido antes permite a articulação do novo com o anterior para ir construindo uma representação em que apesar dos distintos aspectos que se considerem mantém sua estabilidade. Apresentam-se discursivamente como resultado de reflexões suscitadas pela intervenção do outro, "Vou fazer uma reflexão em todo o país em torno ao que Argenis Salazar disse", ou como comentários que se quer fazer: "estamos aqui para ouvir vocês neste domingo 23 de maio, somente talvez dois comentários para todos".

Consideramos, então, que esta emissão expõe o dispositivo enunciativo e os modos de construir os objetos aos que se refere que vai dominar não somente nas seguintes mas também na política comunicacional em que Chávez se envolve pessoalmente. Daí, a importância de considerá-la em sua totalidade como a outros discursos que fundam uma tradição ou que iniciam uma série discursiva extensa. $O$ interesse de se centrar, quando abordamos um discurso fundador ou uma série, nas modulações do intradiscurso, reside no fato de que apresentam condensadamente os traços que se atribuem ao gênero, ao tipo de comunicação que se busca estabelecer ou aos objetos valorizados estrategicamente (ARNOUX, 2008b). O desdobramento discursivo, por um lado, vai instalando o dispositivo enunciativo e, por outro, 
EID\&A - Revista Eletrônica de Estudos Integrados em Discurso e Argumentação, Ilhéus, n. 16 esp. "Discurso e argumentação na política latino-americana, set.2018.

vai modelando as representações que são consideradas fundamentais e às quais se vai voltar ao longo da série. Um e outras intervêm na conformação das subjetividades próprias de cada momento histórico e de cada setor social; no caso que analisamos, da ascensão da revolução bolivariana sustentada popularmente.

Na primeira emissão, o apresentador assinala a excepcionalidade -"é um programa especial, sem precedentes na história da rádio-difusão venezuelana"- e o caracteriza reconhecendo sua condição fundadora:

Pela primeira vez na Venezuela um Presidente da República conduz seu próprio programa de opinião e participação popular, com o único interesse de ouvir o clamor do povo. A partir deste momento e pelo intervalo de tempo de uma hora se estabelecerá o grande diálogo entre o chefe de Estado e vocês que nos escutam agora em toda a República.

"Grande" anteposto a "diálogo" destaca sua importância política, a investidura de quem vai conduzir essa interação (o Presidente da República, o chefe de Estado) e a amplidão máxima que se busca: chegar a "toda a República", ao vivo, em tempo real ("agora"). O programa se inscreve nos gêneros do meio do rádio, é um programa de opinião com um condutor e algum ou alguns membros da mesa com os que também interagem e em que se vai escutar aos ouvintes ("vocês que nos escutam"), mas essa presença do outro já é designada com um sintagma político: ao programa "de opinião" se agrega "e participação popular". O veículo fornece o primeiro formato, mas o sentido não se torna político somente pelo cargo do apresentador, senão também porque se interpela os ouvintes como sujeitos políticos e se valoriza sua palavra em função do lugar que se atribui ao povo na revolução bolivariana. Isto é reforçado pelo sintagma "o clamor do povo", que supõe o desejo de ser ouvido como coletivo mas também remete à força desse impulso derivada da raiva, da indignação, dos problemas urgentes não resolvidos. $O$ discurso dominante no programa assinalará os lugares onde esse povo deve se posicionar, o sentido da luta que deve encarar, a relação com os poderes do Estado e o reconhecimento do outro, daquele que não está no campo popular.

A excepcionalidade surge também das exigências da situação. Assim Chávez vai se referir à "necessidade imperiosa de que o Presidente da Venezuela, como mais um dentre os cidadãos da Venezuela, esteja em contato com a maior parte dos venezuelanos". Colocar-se como "mais um" não apenas se deve à construção de um ethos que ative os laços identificatórios, 
EID\&A - Revista Eletrônica de Estudos Integrados em Discurso e Argumentação, Ilhéus, n. 16 esp. "Discurso e argumentação na política latino-americana, set.2018.

senão que também tende a mostrar a importância da comunicação cidadã. A "necessidade imperiosa" a que se refere deriva de quão decisiva é, para o processo em que se iniciou, a participação de todos (ou a "democracia participativa"), mas também de que ela seja canalizada a partir do aparato estatal, simbolicamente a partir da figura mais autorizada pelo seu cargo. "Estar em contato" implica não somente reconhecer os problemas, mas também implementar os gestos para resolvê-los. Incentivo à participação e disciplinamento das práticas que a tornam possível estão presentes nesta primeira emissão, em que se reconhece a falta de "instituições formadas, não há canais para que o povo se expresse", "o povo não tem quem o atenda, irmão, e são milhões".

Chávez, assim, insiste naquilo que espera dos ouvintes, realizando um deslocamento do midiático para o político: "todos vocês podem se comunicar aqui com a Rádio Nacional da Venezuela também ao longo de toda a semana para deixar suas queixas, seus pedidos, tudo, todas essas vozes, vocês têm que falar porque nós todos vamos salvar o país". Os ouvintes são convocados, em primeiro lugar, a realizar algo que o meio aceita, e impulsiona em alguns casos, que são as propostas dos ouvintes para que sejam retomados pela audição, prévia seleção dos que se consideram mais significativos ou que servem em um momento para o desenvolvimento daquela. Porém, neste caso, fala-se de queixas e pedidos que serão recebidos por quem tem o poder de resolvê-los ou de derivá-los às instâncias correspondentes, o que já não é habitual. E se dá um passo mais: o direito à palavra implica a obrigação cívica de falar já que seu objetivo é "salvar o país", tendendo a conformar uma nova identidade dos venezuelanos, sobretudo daqueles antes deixados de lado como sujeitos com capacidade de incidir nos destinos da pátria. O desejo de conseguir a unidade diversa e ampla se expõe na reiteração de "tudo": "todos", "todas essas vozes", "todos vamos salvar o país", e o "nós” inclusivo ao colocar em pé de igualdade o presidente com os interpelados eleva a estes graças à ação da política. Nesta primeira emissão, a valoração da política e a ideia de que "todos" são responsáveis são dois eixos centrais da discursividade pública de Chávez. Esta responsabilidade exige também a visibilidade dos funcionários que nesta emissão somente são nomeados mas que na série serão postos em cena. Adverte-se além disso aos que não querem mudar "os procedimentos que durante 40 anos trataram de impor" que o povo tem o direito de assinalá-los graças às possibilidades que abre o meio: 
EID\&A - Revista Eletrônica de Estudos Integrados em Discurso e Argumentação, Ilhéus, n. 16 esp. "Discurso e argumentação na política latino-americana, set.2018.

"se vocês veem que não os atendem bem ou que os atendem mal me digam por aqui, por esta via".

\section{Sobre o formato}

Nesta primeira emissão, estabelece, como esboçamos antes, a cenografia própria da mesa de jornalistas com suas funções e hierarquias, em que intervêm também aqueles que realizam as tarefas de produção, que estão no lugar mas não tomam a palavra. As exigências do meio lhe permitem despojar a sua imagem dos traços associados tradicionalmente com a figura de presidente e mover-se com soltura, enquanto autorizado pelo formato, em relações de proximidade com uma audiência que deve conquistar para o êxito do programa. Mas também sua condição de presidente o autoriza a assumir posições políticas e a falar a partir desse lugar. O deslizamento de um papel a outro se expõe discursivamente facilitado pela dupla isotopia que se desempenha no "programa" (de governo e do meio de comunicação) e "apresentador" (da transmissão de rádio e do povo da nação).

No seguinte fragmento, por exemplo, o "eu" individual ligado ao espaço do programa jornalístico passa a um "nós" coletivo animado pela paixão patriótica, que inclui a todos os responsáveis do programa e, finalmente, um "nós" que remete a partir de outro lugar ao "eu" mas desapegado de sua condição de indivíduo -"não somos nem sequer nós mesmos..."- ou aos que participam do outro programa, o político:

Eu sou parte desta equipe de comunicação, de trabalho. Adiante. Todos os operários ou empregados, jornalistas, trabalhando, com honestidade, como nós sabemos fazer, com entrega em prol país, é o país o que nos importa, não somos nem sequer nós mesmos...

Chávez se apresenta como integrante de uma equipe, a da rádio, que se formou para "levar sua voz, para levar a verdade, para levar nossas angústias, nossas impressões a todos vocês, queridos compatriotas" (mais adiante vai dizer "por todo o território bolivariano desta pátria nossa"). O "nós" se desloca aqui da equipe da rádio ao governo e, particularmente ao primeiro mandatário, graças a expressões ancoradas em uma subjetividade: sintagmas em que os núcleos são emotivos (angústias) ou aludem a percepções em geral individuais (impressões).

Como apresentador jornalístico nomeia a todos, os interpela, os designa como destinatários primeiros em alguns casos, os valoriza e expõe ante a 
EID\&A - Revista Eletrônica de Estudos Integrados em Discurso e Argumentação, Ilhéus, n. 16 esp. "Discurso e argumentação na política latino-americana, set.2018.

audiência um trabalho de equipe seguindo as normas do gênero. $O$ estilo próprio do programa jornalístico vai permanecer quando a emissão for televisionada e também vai se projetar a outros formatos, reuniões de gabinete por exemplo. Nesta emissão inicial, diz: "Bom dia, Freddy, bom dia, Teresita, bom dia, a toda a equipe da Rádio Nacional da Venezuela, bom dia a Juan Barreto, bom dia a todo a equipe que estamos formando". Demonstra conhecer os vínculos familiares dos que colaboram. Ao elogiar a diretora da emisora, diz referindo-se ao marido: "Chino já deixou de fumar? [...] Se Teresita não pôde com ele, o Chino é um Chino rebelde". Combina a familiaridade com o formal destacando nos membros da "equipe", além do gesto afetuoso "amigos", sua condição, profissional ou política, ou seu posto na rádio: "Sim, dizia o Licenciado Freddy Balzán, amigo, Diretor da Oficina Central de Informação", "está Pedro Grespan por aqui, deputado e amigo". Saúda a todos os estamentos da atividade radial: "saudações a sua diretoria, a seu pessoal, a seus empregados, seus operários, seus locutores jornalistas". Alude às condições materiais nas que se desenvolve a emissão: "Ah, tu também tens microfone, olha, temos três microfones. Estão muito bonitas as instalações da Rádio Nacional".

Além de ouvir e responder aos ouvintes e comentar as propostas, Chávez fornece informações diversas. Por um lado, sobre as atividades institucionais do presidente: "na terça eu parto para Cartagena de Indias para a Cumbre de la Comunidad Andina de Naciones e daí vou direto ao México, onde se reunirá a cumbre do Grupo do Rio...". Mas também atende à função da rádio de dar informações práticas que vão de números telefônicos de interesse a indicações sobre os lugares aonde podem ir reclamar: "temos que informar-Ihes a todos os venezuelanos onde funcionam os comandos de Teatros de Operaciones Sociais, não são teatros de operações de guerra, não, são abertos à sociedade [... ] o número 1 abarca o Distrito Federal, o Estado de Miranda e o Estado Vargas [... ] devemos ter aqui um mapa com tudo isso para eu poder indicar-lhes aonde vocês devem ir". Além disso, se refere a temas que comovem a população nesse momento: "vou conversar com os pais dessa menina que está sequestrada, nós fizemos todos os esforços como temos que fazer, estamos indagando, investigando, não posso dizer coisas porque poderia afetar a investigação".

Pede precisões acerca dos problemas que os ouvintes colocam e, ao responder, põe em evidência o conhecimento das situações que afetam o 
EID\&A - Revista Eletrônica de Estudos Integrados em Discurso e Argumentação, Ilhéus, n. 16 esp. "Discurso e argumentação na política latino-americana, set.2018.

Estado e o país, em que se conjugam, como dizemos, o papel do jornalista responsável que conduz um programa de rádio e o do presidente comprometido com sua tarefa:

Vou te fazer uma pergunta para tratar de precisar melhor o problema. Tu cobras pelo Estado Vargas ou cobras. Quem paga teu salário?

[... ] aí está o primeiro problema. Criaram o Estado Vargas de maneira atropelada [... ] eu me manifestei contra a criação do Estado Vargas naquele momento [...] e ocorrem problemas como este que não se previu, talvez, imagino, neste caso, como transferir recursos do Distrito Federal ao Estado Vargas recém-criado.

O formato de rádio de um programa de opinião permite também que o presidente se comporte como o apresentador jornalístico que está disposto a ajudar a audiência adotando uma posição que pode implicar o compromisso, o que sua função, aliás, reforça: "Diz a teu pai que haverá justiça. Eu mesmo vou me encarregar disso"; "Eu vou averiguar imediatamente, eu vou questionar isto"; "estamos te ouvindo, presta atenção, tomando nota”. É um presidente / apresentador receptivo às preocupações do povo, que se manifestam em diferentes ocasiões: "Ontem fomos a Puerto Nutrias, há uma linda ponte lá no Apure e me diziam as pessoas, a ponte está caindo, está se movendo, menino". A voz do povo e a voz do locutor se enlaçam expondo no nível discursivo o vínculo político entre povo e líder.

Desliza-se de um lugar a outro acentuando a dimensão pedagógica da sua discursividade que mostra a um jornalista informado como a um presidente conhecedor das decisões institucionais. Nesta ocasião a respeito de que um ouvinte Ihe perguntou: "Que importância tem para o povo venezuelano o Fundo de Estabilização Macroeconômica", que deriva da renda petroleira. Abundam os dados, as estatísticas claras, a história da decisão e os objetivos. Estabelecem-se os grandes alinhamentos do programa de governo em relação com as distintas rubricas a que se vai atender com esse fundo: $25 \%$ para o resgate da dívida, $35 \%$ para a inversão produtiva, a pequena empresa, e $40 \%$ para

pagar a dívida social que o Estado tem com vocês, queridos compatriotas, ou seja, dirigido esse fundo para a educação, não pode haver crianças fora da escola. Há de se construir escolas, há de se melhorar as escolas, há de se contratar professores, e para saúde especialmente, que está massacrada em todo o país.

Mas também mostra sua preocupação com o estado da cidade, "Caracas faz vergonha" ou pela situação dos aposentados e insiste em que há de se ter 
EID\&A - Revista Eletrônica de Estudos Integrados em Discurso e Argumentação, Ilhéus, n. 16 esp. "Discurso e argumentação na política latino-americana, set.2018.

consciência cidadã além de política: "Então eu convoco a todos os corredores, a todos os patinadores, nós que vamos, eu também vou de vez em quando por aí, que tenhamos consciência [...] Trata-se da pátria de todos e essa é a consciência, de que essas são áreas coletivas e que há de se respeitá-las".

\section{A relação com a audiência}

O vínculo que estabelece com o outro, considerando a audiência próxima ideologicamente, é igualmente de proximidade, o que habilita o vínculo solidário e a aceitação dos mandatos que o locutor impõe. Por um lado, os designa como "amigos" não somente aos que o acompanham na emissão, mas também a aqueles que intervêm a partir do exterior: "não se deixem enganar, amigos, eu tenho certeza de que o povo venezuelano não vai se deixar enganar". Por outro lado, pergunta pelos integrantes da família, pelo nome do filho ou do pai, cumprimenta a família seguindo as formas tradicionais de cortesia "Repassa a eles meus cumprimentos", se despede com "um abraço", também estende o afeto aos vizinhos: "Dá um abraço a todos os vizinhos, a todo o pessoal daí, e bom, meu amor, estou às ordens". 0 afeto pode alcançar a extensão máxima -"Um abraço a todos os meus compatriotas em toda a Venezuela"- e mostrar que é compartilhado, "Amor com amor se paga". Ou vincula os nomes com os nomes de sua família -"Além disso, Elena, teu nome é como o da minha mãe, Elena"- ou conhecidos popularmente: "tens nome de jogador de futebol, aliás, daquele de grande liga". Também pergunta sobre o lugar preciso de onde vem o ouvinte participante, marcando o conhecimento que tem sobre o mesmo -"Tu ligas de Guatire? Como estão os tambores por lá?"; e em alguns casos se refere a uma experiência que teve nesse lugar -"Tu sabes que eu conheço muito El Valle pela minha formação, lá, em Fuerte Tiuna, em Conejo Blanco"- ou recorda alguma pessoa que conheceu ali: "Como está Amelia? Amelia é uma grande costureira, me fez um liquilique ${ }^{2}$, o melhor liquilique pequeno que usei". Ou também traz à cena uma expressão popular: "como dizem lá em teu povoado, em teu bairro "como passarinho na grama". Expõe sua solidariedade e acompanhamento: "Se te colocarem para fora por isto, conta comigo, bom, para atuarmos nós dois e aqueles que tenhamos que atuar contra quem faça contigo uma ação deste tipo"; "fico comprometido contigo, com tua família e

\footnotetext{
${ }^{2}$ Traje social, típico da região do Caribe e dos Llanos, da Venezuela e da Colômbia.
} 
EID\&A - Revista Eletrônica de Estudos Integrados em Discurso e Argumentação, Ilhéus, n. 16 esp. "Discurso e argumentação na política latino-americana, set.2018.

com teus companheiros médicos rurais". Diante da queixa de que é complicado chegar até ele, anota o telefone, destacando que vai tratar de marcar um encontro, é o governante esforçado consciente de sua missão com respeito aos que o elegeram. É também aquele que reconhece o valor do outro e o estimula para que atue socialmente: "Eu tenho certeza de que tu és um dos líderes sociais daqueles com que contamos para a nova Venezuela. Por isso, te parabenizo".

Aqueles que participam, ingressando por via telefônica, são reconhecidos como interlocutores válidos a que se escuta, orienta ou cujo caso se delega às instituições correspondentes do Estado. Esta legitimação da palavra do outro torna esse outro, oriundo em geral dos setores populares, visível. E torna visíveis para a sociedade em seu conjunto os diferentes lugares sociais e geográficos a partir dos quais fala ao povo da nação, que deixa de ser um conceito abstrato na medida em que encarna nas múltiplas vozes que têm direito à palavra pública em instâncias que o próprio Estado estabeleceu. O meio atua deste modo na conformação de uma identidade nacional diversa, necessária para o avanço da revolução bolivariana.

Nesse sentido, o auditório é designado também como "compatriotas", o que permite desencadear uma das linhas centrais da discursividade de Chávez, o patriotismo, e ativar uma analogia que não se explicita entre o mandato presidencial e o renascimento da pátria: "esta pátria que renasce, que se encontra em pleno processo de ressurreição". Ao mesmo tempo, o último termo associa a velha pátria ao sacrifício e a nova à vida eterna, à salvação, dentro de uma isotopia religiosa.

A dimensão política se reforça com uma interpelação ao "povo" para que participe no êxito da Assembleia Constituinte:

Esse povo que quer, que está convencido de que aqui há de se fazer uma revolução pacífica [... ] eu vou dar a vocês uma missão a mais, busquem mais um daqueles que não votou, um, convençam um, e vão acompanhando os que não votaram, convençam eles, vão atrás deles e convençam eles.

\section{O ethos}

O início de um contato assíduo e regular com a população através de um meio de comunicação amplo afirma e potencializa a matriz da discursividade política de Chávez. Nisso, a representação de si, do ethos em termos retóricos, é central para gerar a confiança (aquele que fala é sincero, eficaz e 
EID\&A - Revista Eletrônica de Estudos Integrados em Discurso e Argumentação, Ilhéus, n. 16 esp. "Discurso e argumentação na política latino-americana, set.2018.

competente) e ativar os mecanismos identificatórios que façam com que o povo assuma as tarefas que o projeto bolivariano exige. Constrói assim uma figura diversa na qual não somente assume diferentes papeis discursivos mas que também se refere às múltiplas atividades que realizou ou realiza mostrando-se como um homem dentre outros. Porém, ao mesmo tempo, vai modelando a imagem do líder revolucionário. Estes procedimentos que se expõem em um discurso auto-centrado (ELRICH, 2005a) são decisivos na construção daquilo que Charaudeau (2005) chama de um ethos de credibilidade (que implica em que a palavra seja convincente) e um ethos de identificação (em que a capacidade de mobilizar ao outro se baseia na identidade que se busca compartilhar).

\section{Um homem como os outros}

Nessa construção do ethos, o "eu" pode distanciar-se e falar da função institucional em terceira pessoa, o Presidente da Venezuela, que é o que legitima oficialmente o emprendimento e Ihe atribui a capacidade de responder às demandas da audiência. Mas reiteradamente aparece o "eu", como vimos em exemplos anteriores, mostrando a importância que tem nessa primeira emissão modelar uma representação de si, que, assim como expõe traços já conhecidos de Chávez, os acentua.

Apresenta-se como membro da equipe de rádio na qual sua função se afirma no fato de ele ser também locutor: "sou locutor, tenho meu título, e, bom, isso ajuda um pouco. Somos colegas de alguma maneira". Esta referência mostra o velho interesse de Chávez pelos meios e a consciência de sua capacidade para operar nesse âmbito, em que pode atuar como um profissional.

A indicação de outras atividades que realizou o mostra como alguém que conhece a vida, que pode colocar-se no lugar do outro, que carece do engessamento habitual do cargo: "Eu era apresentador de espetáculos folclóricos, então, eu uma vez apresentei a Reyna Lucero lá na Academia Militar e disse: aqui conosco está a rainha de Aragua e estrela da Venezuela, Reyna Lucero! Eu fiz muitas coisas, Juan, tu sabes". Esse "ter feito muitas coisas" permite a Chávez assumir os diversos papeis que a emissão vai exigindo, necessários, além de tudo, para manter o interesse da audiência. Neste caso, o exemplo, "apresentador de espetáculos folclóricos", anuncia uma linha importante da discursividade de Chávez: as múltiplas referências a 
EID\&A - Revista Eletrônica de Estudos Integrados em Discurso e Argumentação, Ilhéus, n. 16 esp. "Discurso e argumentação na política latino-americana, set.2018.

aspectos diversos da cultura popular e o entusiasmo por cantar fragmentos de canções populares venezuelanas.

Para atar o vínculo com os que reclamam por aposentadorias ou pensões, refere-se a sua condição de pensionista:

Eu também sou pensionista. Eu estou aposentado. Tenente Coronel aposentado. Inclusive, como cobro minha pensão, bom, que também não é uma coisa do outro mundo uma pensão de Tenente Coronel, dá para manter os filhos, para as coisas mínimas da vida, eu decidi dar meu salário de presidente como bolsa para três estudantes venezuelanos, e isso já está acontecendo.

Fala sobre um tema não habitual, seus rendimentos, os avalia e mostra por um lado a transparência que deve reger os atos que afetem os funcionários, mas também apresenta os gestos solidários que podem ser seguidos por outros, ao mesmo tempo em que valoriza a educação: o destino dos fundos é para algumas bolsas estudantis.

A partir de uma intervenção sobre a situação das prisões, refere-se a sua situação como preso:

Lembro que, estando preso [...] várias vezes o tribunal aconteceu e se instalou [...] Voltei a Yare não chorando pelas recordações do tempo que passei ali mais nada, porque a gente desenvolveu um carinho, sim, a gente desenvolve carinho pelos lugares, dois anos e meio ali aprendendo, semeando, pensando na Venezuela, senão pelo inferno do povo que vive ali.

Mostra-se, assim, como alguém que sabe daquilo que fala e também como um sujeito que se comove pelo "inferno do povo que vive ali". Além disso, mostra afeto por essa etapa da sua vida porque foi fundamental em sua formação e na de seu grupo político de pertencimento: "aprendendo, semeando, pensando na Venezuela". A revolução bolivariana se semeou na prisão, é filha do sofrimento mas também da vontade de superação (aprendendo, pensando). O presidente se apresenta como modelo já que extrai o positivo das circunstâncias difíceis que teve que enfrentar, e, para que esse gesto seja possível, é necessário fazer a reflexão política, a convicção de que o destino individual se ata ao do amplo coletivo a que pertence, a Venezuela.

Do mesmo modo, apresenta-se como mais um, que tem como muitos uma família a que se refere em distintos momentos, inclusive Chávez faz gestos comuns como mandar, da audição, um beijo para sua filha. Quando se Ihe apresenta o mal estado de uma rua põe uma de suas filhas em cena: “María Gabriela me dizia que caminhou por Los Próceres e me dizia: Papai, me 
EID\&A - Revista Eletrônica de Estudos Integrados em Discurso e Argumentação, Ilhéus, n. 16 esp. "Discurso e argumentação na política latino-americana, set.2018.

deu vergonha isso. Faz alguma coisa". Depois de nomear seus filhos e suas respectivas idades diz referindo-se a uma de suas filhas, a que coloca em uma cena simples, comer manga, que a mostra como uma menina próxima por seus gostos e em torno de muitas outras:

Rosa Inés, que lá ficou comendo manga esta manhã, porque todos os dias come manga essa menina, eu a chamo 'a come manga'. Se põe de pé e já acostumadinha, vai para as mangueiras, aí para pegar mangas. Bom, Rosa Inés tem um ano e meio, quando Rosa Inés, minha menina, como todos os meninos da Venezuela e lhes mando minha benção por aqui, porque todos são como meus filhos, quando eles sejam pensionistas, dentro de 50, de 60 anos, meu Deus, que não estejam passando as de Caim.

O gesto solidário se conjuga com a sensibilidade quanto ao sofrimento dos mais fracos, que se manifesta também, quando fala de sua infância, com relação às crianças pobres:

Eu fui uma criança feliz. Por isso, vejo as crianças pobres e tristes e me corta a alma. Eu fui uma criança feliz. Muito pobre, descalço, de chinelas, vendendo doces na esquina da praça mas feliz. Trepado em uma laranjeira, comendo mangas, comendo naranjas, e eu gostaria que todas as crianças, ainda que fossem pobres, fossem felizes.

Embora a dor seja dita, a felicidade é mostrada sobretudo (MICHELI, 2014) graças à cena de sua infância que esquematiza (GRIZE, 2004), o que lhe atribui maior força argumentativa. Com isto, busca romper a associação comum pobreza / infelicidade e valorizar a alegria como motor vital que não surge do gozo econômico senão dos prazeres simples da vida e do desfrutar os "sabores" que podem ser alcançados. Isto sustenta a luta contra o consumismo dominante e promove as bases morais do socialismo. Além disso, ativa a emotividade como forma de consolidar os laços políticos.

Nesse mostrar-se como mais um, aparece a paixão desportiva, a chateação porque a imprensa diz que "se ponchó"3 em uma partida de softball e ele, apesar de que reconheça que não estava treinando, relata os êxitos que teve nessa partida, empregando os termos próprios da gíria do jogo e encerra: “mas não me ponché e a todo jogador de futebol lhe dói que batée un hit o un ... e digam-lhe que se ponchó. Yo no me ponché. Mas, em todo caso, jogamos uma partida com o general Cruz Wefer e ganhamos, ganhamos a equipe do Círculo Militar. Tinha como oito anos que não ganhava um jogo de softball, meu Deus, estou como ressuscitando. Graças a Deus". O expor os gostos

\footnotetext{
${ }^{3}$ Diz-se quando o jogador de softball é eliminado da partida.
} 
EID\&A - Revista Eletrônica de Estudos Integrados em Discurso e Argumentação, Ilhéus, n. 16 esp. "Discurso e argumentação na política latino-americana, set.2018.

pessoais, que, além de tudo, são compartilhados por muitos, facilita os processos identificatórios e seu deslocamento ao político.

Apresenta-se, então, como político comprometido com o que propõe. Esse compromisso pode expor em termos coloquiais ou estender-se em uma linguagem política que incorpora matizes heróicas que comprometem também ao povo, associada com a imagen de uma força irresistível que se lhe impõe:

[...] minha responsabilidade não é com governadores, nem com particulares nem com partidos políticos, senão meu compromisso, eu cheguei aqui empurrado por esta corrente popular bolivariana para governar para os venezuelanos e pelos venezuelanos e nisso empenho minha vida inteira, em frente, e que Deus nos acompanhe.

O "empenhar a vida inteira", a serviço do povo, é algo que reitera em outras ocasiões mas que seu comportamento reforça. Os seguidores destacam, assim, sua capacidade de trabalho, o estar atento a tudo, o descansar muito pouco e o responder às exigências de sua própria política comunicacional, de que Aló Presidente será a expressão mais clara. Nesta primeira audição, ele mesmo se refere ao acúmulo de tarefas oficiais que tem e, em parte, ao esforço pessoal que implica:

Olha só, o Presidente da República é Comandante em Chefe das Forças Armadas. Ontem à noite, estive até as três da manhã revisando os expedientes dos oficiais que estão propostos para os ascensões. Além disso, sou quem dirige a política exterior da Venezuela, agora vou a Táchira, venho à noite para trabalhar com uma equipe, preparando minha intervenção [...]. Além disso [...] o problema da menininha lá na fronteira, além disso, o problema da administração pública nacional.

O destaque dessas atividades em uma emissão de rádio em que dialoga com os ouvintes sobre temas diversos tornam mais próximas tanto a figura presidencial como as funções oficiais.

Ao que retorna com insistência é a sua condição de militar: "sou um soldado, vocês sabem disso". A figura do soldado se inscreve no cronotopo bolivariano (ARNOUX, 2008a): remete às guerras da independência como momento inicial, mas que permanece à medida que a independência não se completou, já que outros impérios tomaram o lugar do espanhol. Mas também a figura do soldado está além das hierarquias e ativa o imaginário da revolução democrática, da busca de um universo de iguais. Esta impõe novas formas de liderança: "os novos líderes sociais, temos que ser líderes sociais 
EID\&A - Revista Eletrônica de Estudos Integrados em Discurso e Argumentação, Ilhéus, n. 16 esp. "Discurso e argumentação na política latino-americana, set.2018.

comprometidos com esse teu povo, Argenis, mas não com partidos políticos nem com cúpulas, nem tratar de utilizar essa liderança em função de interesses pessoais".

\section{Um líder revolucionário: o que não aceita "mordaças"}

A sinceridade como valor surge não somente de romper com a imagem estereotipada associada com a investidura presidencial senão também do gesto de se localizar no lugar daquele que profere uma palavra verdadeira diante da mentira dos adversários. O dizer sua palavra, a palavra que crê verdadeira sem medo daquilo que possa acarretar responde à representação, que Foucault (2009) destaca, do revolucionário. Daí a insistência em referir-se, nesta primeira emissão, em termos de "mordaça" a todos os obstáculos que teve que enfrentar na luta política.

Primeiramente, apresenta-se como vítima dos que querem a mordaça. No seguinte fragmento, a passagem ao "nós" dá a possibilidade de que se incluam outros sem definir quem são e o deslocamento final para a terceira pessoa ao destacar a investidura exibe o impróprio do gesto, "que ande com a boca fechada":

Querem me colocar uma mordaça, uma camisa de força [...] vimos vencendo camisas de força, vimos jogando-as abaixo, vimos rompendo amarras que nos querem colocar [... ] alguns querem que o presidente ande com a boca fechada.

Reformula "mordaça" em "camisa de força", "amarras" e "a boca fechada", e cada um dos termos embora se vincular com os outros tenha sua especificidade significativa: a "mordaça" impede de falar como "a boca fechada" mas a primeira é imposta por outro ao mesmo tempo em que "a boca fechada" pode ser um gesto individual de auto-censura; as outras, "camisa de força" e "amarras" impedem a libertade de movimentos mas a primeira inclui a loucura como causa. A reformulação intradiscursiva incide na densidade do fragmento e as unidades léxicas que integram a série não somente reforçam o significado base senão que também abrem outras vias interpretativas sobre as pressões que se exercem sobre o presidente e o movimento político que representa e, inclusive, sua valoração: é uma loucura (por isso é necessária a "camisa de força") a mudança política que desencadearam. O gesto enérgico de rejeição a essas pressões enuncia que o que vai circular pela rádio é uma palavra verdadeira, que surge de convicções 
EID\&A - Revista Eletrônica de Estudos Integrados em Discurso e Argumentação, Ilhéus, n. 16 esp. "Discurso e argumentação na política latino-americana, set.2018.

profundas, que vai poder interpelar aos outros desde a honestidade e a sinceridade: que "isto sirva para buscar a verdade, para que nos digamos e busquemos a verdade". A repetida frase bíblica, "aquele que tenha olhos que veja e aquele que tenha ouvidos que ouça”, remete a que essa verdade pode ser percebida por aquele que tem as condições para fazê-lo, mas se efetua o deslocamento: o objeto não é somente o que circula pela emissão senão também a própria revolução bolivariana. Esta sustentou a liberdade de expressão inclusive em momentos difíceis. González Binetti (2012, p. 70) assinala: "Na Venezuela há centenas de cadeias que questionam dia e noite as ações do regime. Parece difícil falar de uma confisco da palavra ou da liberdade de expressão".

O exercício da liberdade de expressão deve estender às intervenções dos ouvintes. As palavras que eles profiram permitirão conhecer a realidade venezuelana nos diferentes lugares que cobiça o Estado, identificar necessidades e projetos e atuar, em consequência. Mas também permitirá o controle do aparato estatal pelo fácil deslocamento da queixa à denúncia, que de alguma maneira autoriza o próprio presidente.

A luta contra a mordaça, as amarras ou a camisa de força remete também metaforicamente a todos os impedimentos que se sucederam no caminho da revolução e que foram vencidos. Esse fio lhe permite historicizar com tons épicos o processo recente, no qual se conjugam a vontade de luta e a participação popular (sublinhada com a presença insistente do lexema "povo") da que torna partícipe a audiência, a que atribui o reiterado apelativo afetivo "amigos":

As primeiras amarras foram as da prisão, graças a um povo saímos dali. Segundo, cruzamos um deserto, perseguidos por todos os lados, difamado por todos os lados. Chegamos o ano passado, em 98 e também queriam colocar-nos camisa de força, o povo as venceu, as derrubou, os obstáculos, as amarras, o 6 de dezembro, de que maneira linda, vocês, amigos. [...] De todo modo, vencemos essas amarras.

A épica passada, acentuada pela referência bíblica "cruzamos um deserto", se projeta ao presente, apesar do triunfo eleitoral e do poder institucional que Ihe outorga. Os obstáculos são jurídicos mas se inscrevem na mesma linha de evitar o avanço da revolução:

Então, recordemos, amigos, que chegamos à presidência e ainda querem nos amarrar. Queriam amarrar o referéndum. Vocês lembram, decretei o referéndum, o decreto para chamar referéndum e o impugnaram 15 vezes na 
EID\&A - Revista Eletrônica de Estudos Integrados em Discurso e Argumentação, Ilhéus, n. 16 esp. "Discurso e argumentação na política latino-americana, set.2018.

Corte Suprema. Queriam nos amarrar, também vencemos essas amarras. Agora alguns querem que o presidente ande com a boca fechada.

Nesta primeira emissão, em que domina o jogo entre locutor de rádio e presidente, a figura do revolucionário - para Foucault (2009, p. 86), uma das grandes figuras da "dramática do dizer verdadeiro na ordem da política"somente aparece sob a forma do parresiasta, em outros momentos the associaram novos atributos.

\section{A Constituinte e aquilo a que se enfrenta}

Esta primera emissão mostra não somente a importância que se atribui à participação popular na comunicação de suas demandas e na gestão de empreendimentos de diversos tipos mas também a valorização das formas representativas republicanas já que a Assembleia Constituinte é um objeto de discurso central porque é a forma de "apoiar a transformação e o projeto bolivariano do futuro do país". Como é também o objetivo imediato, a dimensão política se acentua com ele e marca enfaticamente aquilo a que se opõe. Ainda que em um momento Chávez declare, tendendo a mostrar a moderação de um homem de Estado, "não tenho inimigos. Amigos adversários!", a polarização associada com os gestos polêmicos (AMOSSY, 2014) se impõe. Assim, a desqualificação é forte e apela com insistência à isotopia do engano, mentira, ocultação.

A alta abstenção no referéndum foi uma das razões que possivelmente impulsionou a necessidade de implementar uma política comunicacional, um de cujos pilares é Aló presidente: "foi muito alta a abstenção, isso há de se reconhecer, nós avaliamos". O resultado é esta forma de aproximar-se ao povo, de receber suas inquietações, de explicar o programa político, de construir os imaginários que o façam possível. A confiança na estratégia midiática sustenta a decisão de intervenção regular e em um horário familiar através da rádio. Também o desejo declarado de lutar contra a mentira, que como assinalamos é um tópico reiterado nesta primeira emissão: “aqui na Venezuela às vezes até se abusa, se denigre, se mente, se lançam campanhas de difamação por alguns meios de comunicação, mas eu fui em parte vítima também, muitos de nós, eu apenas mais um".

Insiste, frente à abstenção e à campanha dos opositores, na importância das eleições: "vocês, queridos amigos, têm que ir todos votar, e votar pelos melhores homens, pelas melhores mulheres, pelos patriotas”. Quando se 
EID\&A - Revista Eletrônica de Estudos Integrados em Discurso e Argumentação, Ilhéus, n. 16 esp. "Discurso e argumentação na política latino-americana, set.2018.

apresenta a ocasião nomeia aos candidatos para a Constituinte para fazê-los visíveis e aproximá-los à audiência: "Reyna vai ser candidata", "Cristóbal Jiménez também, 'El coplero de oro de Mantecal' como candidato à Constituinte para Apure"; "o ministro Reyes Reyes, que também vai à Constituinte pelo Estado Lara".

Ao longo da audição, Chávez retorna insistentemente ao tema da Assembleia Constituinte. O objeto vai se construindo assim desde diferentes perspectivas em um permanente retomar e ampliar ou acentuar determinados aspectos. A retomada se dá diretamente ou acrescentando algo que se está dizendo com a necessidade da Constituinte, daquilo ao que tende e ao que se opõe. Esse retornar mostra que é um objetivo importante nesse momento. Pode aparecer em uma posição subordinada: "isso forma parte de uma ideia, William, constituinte". Ou ser nomeada humoristicamente: "Tem corridas de cavalos hoje, Juan, tu tens alguma linha? A minha linha é Constituinte". O objetivo central é instalá-la como objeto de posicionamentos e debates. Por isso, apresenta a Constituinte como aquilo que enfrenta "os quarenta anos de desmoronamento institucional, de imoralidades públicas", "os modelos neoliberais".

Os inimigos do chamado a uma assembleia constituinte são designados como "encapuzados", "mascarados", “enganadores", são os que não expõem suas verdadeiras intenções nem sequer sua identidade: "os adecos não querem dizer que são adecos, os copeyanos não querem dizer que são copeyanos" ", "estes que querem se mascarar, que querem se disfarçar de independentes", "eles estão tratando de enganar", os "encapuzados independentes" como se designa a eles, em diferentes momentos da emissão. Esses modos de designar o outro, aquele que se opõe, permitem operar a exclusão ao mesmo tempo em que estão associados aos anti-valores do engano e a mentira, facilmente compreendidos pela sua audiência. E esses anti-valores se projetam politicamente ao gesto que assumiram: são "os que impugnaram o referéndum". Opõe-se a eles claramente os membros do movimento bolivariano que não somente devem estar dispostos a dizer sua verdade, mas também a participar do processo constituinte: "os venezuelanos temos que ir à Assembleia Constituinte no 25 de julho para dizer 'Não' ao continuísmo, não a esses encapuzados que agora querem se mascarar como

\footnotetext{
${ }^{4}$ Adecos, termo utilizado para designar apoiadores ou filiados ao partido Acción Democrática (AD). E Copeyanos, apoiadores ou filiados ao partido Comité de Organización Política Electoral Independiente (COPEI).
} 
EID\&A - Revista Eletrônica de Estudos Integrados em Discurso e Argumentação, Ilhéus, n. 16 esp. "Discurso e argumentação na política latino-americana, set.2018.

independentes"; "eles têm o direito a se mascarar, nós não, nós lhes tiraremos as máscaras". O não poder dizer o que se pensa por parte dos que se opõem ao processo bolivariano se deve ao inconfessável de seu agir e desmontá-lo exige o apoio popular: "Nós estamos desmontando esses mecanismos de corrupção, de burocracia, de travamento, mas não será fácil. Estamos ali e necessitamos o apoio de vocês [...] especialmente e volto a insistir, estamos em tempos da Constituinte para desmontar tudo isso".

Como vemos, a partir do objetivo imediato que é a Constituinte vai definindo o fora, aqueles que enfrentam o projeto nacional bolivariano. Como é próprio das revoluções democráticas, o inimigo do processo revolucionário é também o inimigo da nação, inclusive nas revoluções "pacíficas", "democráticas" e "não violentas" como a que propõe Chávez. Isto se projeta também ao passado: “em 100 anos, a Venezuela veio se afundando no desastre"; “o último meio século, este de 1950 para cá aproximadamente, é a etapa mais obscura da história republicana da Venezuela". Em relação com o passado recente, opõe seu programa de governo ao desperdício dos que o precederam, que não se preocuparam pelo bem comum: "Não vamos cair na armadilha de estar gastando em burocracia, em festas, derperdiçando dinheiro em viagens, como aconteceu em anos anteriores".

A proximidade do ato eleitoral acentua a dimensão polêmica e motiva o gesto indignado frente à conduta dos outros: "A Constituinte nos permitirá fazer justiça, que haja um poder judicial que prendam os responsáveis pelo roubo", que "Ihes tirem o que roubaram"; "quando a gente diz que destruíram o país não é mentira, o destruíram. As pontes caem sozinhas"; "Temos que criar uma armação institucional democrática, democracia é ouvir o povo e dar-lhe uma mão. Isso é o que temos que fazer, mas com a ajuda de vocês. Vamos à Constituinte"; "a Constituinte é para ir pouco a pouco desenterrando a corrupção, arrancando na raiz os vícios que há em todas as instituições de Estado e em toda a sociedade".

A emissão que põe em marcha é, então, parte dessa "armação institucional democrática", a consideração da democracia e o objetivo do programa se enlaçam. Mas a necessidade de mobilizar o povo faz aflorar o discurso de barricada: "é a batalha social, é a guerra social, o inimigo é a fome, é a corrupção, é a falta de atenção ao povo, esse é o inimigo". Muitos destes enunciados se preparam para o processo de aforização (MAINGUENEAU, 2012) e acompanharão as alocuções públicas de funcionários ou líderes 
EID\&A - Revista Eletrônica de Estudos Integrados em Discurso e Argumentação, Ilhéus, n. 16 esp. "Discurso e argumentação na política latino-americana, set.2018.

populares, e poderão ser arvorados em carteis. Participar com energia nessa batalha define sua posição militante: "sim, estou em combate, mais que em campanha, em combate". Combate em que ele tem sua responsabilidade: "eu o que ando fazendo é cumprindo com uma responsabilidade". Esta se torna mais que do cargo, dos requerimentos do processo revolucionário.

Associa a data da Constituinte com o nascimento de Bolívar. A comemoração ativa a memória da luta independentista, e lhe permite retomar os tópicos da independência, a democracia "sólida", a justiça social e reformular a "camisa de força" como "correntes". A revolução não está nomeada, mas o sintagma "revolução pacífica" dito em outros momentos da emissão aflora no romper "pacificamente":

[...] além disso, em menção honrosa a Bolívar, porque Bolívar nasceu na meianoite do 24, amanhecendo no 25, nós vamos levantar nossa bandeira. Independência para ter uma democracia sólida, para ter um sistema político e social justo, que se acabe toda esta injustiça, toda esta trama, toda esta camisa de força, para romper estas correntes pacificamente.

O discurso adota os tons do manifesto e da luta. O processo alcança assim a dimensão épica que requerem as transformações projetadas: "já não é nem por nós a Constituinte, é para nossos filhos".

No fechamento da emissão, o chamamento se intensifica retomando as construções anteriores:

[...] abrindo o caminho, construindo a Venezuela do próximo século, a nossa Venezuela, vamos todos à Constituinte no 25 de julho. A Constituinte dos patriotas, a Constituinte do futuro. Não às máscaras, não ao carnaval, não ao engano, vamos batalhar pela verdade. Triunfaremos pela Venezuela.

\section{A representação do processo revolucionário: a união do povo e o exército}

$\mathrm{Na}$ representação que Chávez busca construir do processo revolucionário, a sua figura como articulador dos dois pilares, povo e exército (comum a muitos movimentos nacionais e populares de países periféricos), é essencial frente a instituições deterioradas, fragilidade do tecido social e um aparato estatal relutante em algumas zonas a encarar as novas tarefas (governadores e prefeitos "que não querem se integrar”). Esta convergência entre povo e exército, que ele encarna, funciona como modelo para uns e outros e tenderá ao disciplinamento do primeiro e à lealdade ao povo, ou o conceber-se como parte dele, do segundo. 
EID\&A - Revista Eletrônica de Estudos Integrados em Discurso e Argumentação, Ilhéus, n. 16 esp. "Discurso e argumentação na política latino-americana, set.2018.

Chávez o ilustra se mostrando, como assinalamos antes, como um elemento a mais de uma corrente política ampla ("esta corrente popular bolivariana") a que lhe atribui o caráter de força imperiosa. Em relação a isso aparece uma imagem, que vai a ser recorrente entre rio e povo (ARNOUX, 2015), e a introduz assinalando que ele é rio:

Eu sou como o rio, e entro no rio e sinto que vibro com esse rio que corre e que vai até o mar e que nunca se detém, e o povo não me deixou [navegar el Apure] mas igual de feliz porque há um rio de povo [...] É um rio que corre, vocês são em rio, em revolução moral, é um povo que ressuscitou e eu me sinto contente porque quando um povo ressuscita não há nada nem ninguém que o detenha.

O que vai tender à identificação de Chávez e o povo (Chávez é o povo/o povo é Chávez) se esboça mediado pela metáfora do rio: eu sou rio / "um rio de povo". A referência a um "rio, em revolução moral” leva a que se leia em isotopia religiosa o ressuscitar. À força da natureza se une a força divina.

A apelação ao povo para que construa a memória de sua luta e ao fazêlo, sua própria identidade, se nutre de enunciados valorizadores. Em relação com o tema da "mordaça" ao que nos referimos antes diz:

Porque vocês venceram os obstáculos, as amarras no 6 de dezembro [...] Porque vocês são parte ou são o povo mais glorioso da América, um povo que criou liberdades, um povo estóico, lutador, paciente, um povo bolivariano, um povo de poetas e também de guerreiros, de gente de combate, de muita força.

Assim como constrói discursivamente a representação do território da nação, de sua geografia e de sua gente, nas diversidades sociais e de paisagens, mas na unidade que o constitui, constrói a representação do povo venezuelano, que gerará os mecanismos identitários capazes de estimular o sentido épico de sua luta. Por momentos, a categoria "povo" pode alcançar sua extensão máxima: "o povo é o mais importante, o ser humano é o mais importante entre céu e terra depois de Deus". A luta contra a desigualdade é também uma luta pela espécie humana.

Por sua parte, o exército é associado às tarefas organizativas, de gestão e controle. Chávez mesmo se coloca como militar nesse lugar: "para a partir do meu lugar de mando, de Presidente, impulsionar a solução”. A confiança nos integrantes da instituição se baseia no conhecimento pessoal: "eu passei com eles 25 anos da minha vida, não vou conhecê-los?", "os conheço um por um [...] a todos meus irmãos e meus alunos e professores também". O exército é a força que permite levar adiante o que a revolução se propõe. 
EID\&A - Revista Eletrônica de Estudos Integrados em Discurso e Argumentação, Ilhéus, n. 16 esp. "Discurso e argumentação na política latino-americana, set.2018.

Além disso, seus membros são apresentados com variadas capacidades que fazem possível o cumprimento de tarefas diversas. Ao caracterizar o general Wefer, assinala que gosta de um esporte popular (o "sempre foi primeiro bate"), que está convencido do valor de sua tarefa ("um homem entregado a isto") ou que tem outras competências, além disso, de ser militar ("é engenheiro").

Detém-se no "Plano ou projeto Bolívar 2000", antecedente das diversas missões que o governo venezuelano vai encarar, e busca estimular a confiança em sua realização:

Eu tenho muita fé nesse projeto. Jogo as cartas nesse projeto, jogo a partida, jogo a Rosalinda, por quê? Porque nesse projeto estão incorporados em corpo e alma a maior parte dos militares da Venezuela, 90\%, há de se deixar um 10\% nos quarteis também.

Vai se construindo uma imagem nova das forças armadas em que o vínculo com o povo é essencial: "as Forças Armadas motorizamo povo, mas junto às comunidades, não é um projeto militar ou militarista. Não, é um projeto popular, é um projeto onde se requer, que necessita do ar, do oxigênio do povo". E insiste:

Eu ontem estive com meus irmãos de armas [...]. Ontem fundamos, criamos, a Brigada Especial para Seguridade e Desenvolvimento [...] Ontem nasceu uma Brigada em Barinas, mas essa brigada não vai ser para andar somente com um fuzil percorrendo as ruas com essa atitude repressiva. Não, não, não, está cambiando o conceito militar.

A mudança implica que o exército participe do desenvolvimento do país e que o militar se mostre em sua capacidade organizativa e em sua eficácia:

De leste a oeste, essa brigada com batalhões de assuntos civis, ou seja, veterinários, agricultores, engenheiros, mestres de obra, pescadores, é uma brigada para o desenvolvimento. São as Forças Armadas em função do desenvolvimento de um povo. Essa apenas é a primeira semente de uma nova Força Armada Venezuelana e ali estão comprometidos em corpo e alma meus irmãos de arma.

Por outra parte, as Forças Armadas permitem, como é sua função primeira, o controle do território: “ontem ativamos uma brigada, os que conhecem o mapa de Barinas pensam e veem a importância disso, uma brigada que está estendida desde Puerto Nutrias [... ] até Duacas de Rivera, um pequeno povoado que está...". Encaram as ações cívicas com estratégia e decisão como se devem encarar as batalhas, dali que se fale do "dispositivo de 
EID\&A - Revista Eletrônica de Estudos Integrados em Discurso e Argumentação, Ilhéus, n. 16 esp. "Discurso e argumentação na política latino-americana, set.2018.

batalha desse Plano" ou de "comandos de Teatro de Operações Sociais". E constituem um sistema para fazer circular as informações: "vão aos comandos [...] e me mandem suas sugestões, suas queixas, suas propostas", "vão aos comandos de operações sociais, aos comandos de guarnição e levem suas queixas, suas propostas", "Tive os relatórios dos comandos de guarnição como vocês contribuíram para levar adiante e agora é quando necessitamos seguir trabalhando no Projeto Bolívar 2000 para melhorar esse desastre". Mas o povo pode informar igualmente acerca da atenção nos quarteis: "estão autorizados para me dizer, veja, eu fui ao quartel tal e lá não me atenderam ou me trancaram a porta ou me prenderam porque também não é fácil mudar todos os procedimentos".

Insiste-se em que a união do povo e do exército é essencial para alcançar os objetivos da revolução, nesta etapa, a luta contra a desigualdade e colocar em marcha um aparato produtivo diversificado: "vamos fazer empresas populares, organizem vocês empresas de manutenção, de construção, agrícolas, de pequenas empresas de pescadores". Deve-se mobilizar o povo organizado: "necessitamos as juntas de vizinhos, associações de vizinhos", "vão se organizando, cooperativas de construção, muitos desempregados, bom, organizem-se, há engenheiros que estão desempregados, há mestres de obra, operários, organizem cooperativas bem sérias, bem estruturadas". A criação de cooperativas será estimulada ao longo do governo de Chávez e se mostra já como um objetivo nesse discurso inicial. A organização popular tem um forte sentido político que se evidencia na gradação dos sintagmas que acompanham o "para”: "o povo organizado, isso é algo fundamental, é a união do povo para o trabalho, para a vida, para o resgate do país". O Estado é que vai enviar os recursos: "vamos enviar recursos diretamente às comunidades", "eu vou fazer chegar a vocês os recursos para que vocês façam suas escolas".

Refere-se com entusiasmo às conquistas que mobiliza o exército: “Em Barinas inauguramos o Comando da Brigada Zamora, em 20 dias, 25 homens, soldados, com um grupo de oficiais e engenheiros, e quarenta empregados dali, de Barinas, operários que estavam desempregados construíram uma instalação”. "Em Guasdalito, um grupo de oficiais, quatro oficiais engenheiros do Regimento de Engenheiros, com 40 soldados e 40 operários da zona de lá de Apure, construíram em quatro meses um liceu, um senhor liceu". Escolas e liceus são objetos destacados no discurso de Chávez já que considera a 
EID\&A - Revista Eletrônica de Estudos Integrados em Discurso e Argumentação, Ilhéus, n. 16 esp. "Discurso e argumentação na política latino-americana, set.2018.

educação como um valor que deve chegar aos setores populares. Os avanços nesse campo foram significativos (GONZÁLEZ BINETTI, 2012, p. 63). O entusiasmo explícito pelas conquistas vai acompanhar seus discursos políticomidiáticos posteriores, inclusive a transmissão televisa das reuniões de governo.

\section{A relação com outros processos históricos}

O projeto que Chávez encara se inscreve, em primeiro lugar, na história pátria. Comemora a Revolução Restauradora de fins do século XIX como o antecedente nacional mais próximo, a que se vincula também familiarmente. Recorda, assim, a participação de seu avô Maisanta, e de llaneros ${ }^{5}$ e andinos que acompanharam a revolução, insistindo em seu caráter popular e nacional já que convocava massas de diferentes lugares. A valorização é significativa já que, embora reconheça que foi sangrenta, era "ao menos nacionalista, que começou a rearticular, a reunificar a Venezuela", "levantou as bandeiras nacionalistas. Defendeu perante o mundo o que é a Venezuela com muito fervor patriótico". O nacionalismo está ligado à busca da reunificação: "o país estava desarticulado", "rearticulou a Venezuela. Conquistou a unidade da Venezuela". Assim como se identifica com essa revolução ("hoje estamos de pé, estamos em marcha, terminamos o século também em marcha") pelo caráter nacionalista e a busca da unidade do país assinala as diferenças: "Terminamos o século também em marcha, em uma revolução não violenta, uma revolução democrática, uma revolução pacífica" e fecha a série de retomadas incorporando o projeto bolivariano: é uma revolução bolivariana, é Bolívar que retorna com sua bandeira de redenção". A longa duração do cronotopo bolivariano (ARNOUX, 2008a) se faz explícita: "os séculos são apenas uma etapa da história". E a comemoração é uma ferramenta que constrói a mudança atual.

Ao se referir à Brigada Especial para a Segurança e Desenvolvimento exalta a figura de Zamora: "colocamos o nome glorioso, eterno do General do povo soberano Ezequiel Zamora". A ativação das lutas nacionais e populares do continente é um imperativo da ideologia bolivariana da qual Chávez é adepto. Embora intervenha consciente e intensamente sobre isso, não pode deixar de se inscrever nessa tradição. O "ser adepto" é a chave de sua

\footnotetext{
${ }^{5}$ Designa as pessoas oriundas da região dos Llanos, na Venezuela.
} 
EID\&A - Revista Eletrônica de Estudos Integrados em Discurso e Argumentação, Ilhéus, n. 16 esp. "Discurso e argumentação na política latino-americana, set.2018.

capacidade de convocatória. Não é resultado de um gesto manipulatório, que como tal não houvesse tido sua potência mobilizadora já que o poder da ideologia é exercido se alguém está submetido a ela.

Mas também outros "próceres" aparecem no universo discursivo, que anunciam outros recorridos mas que se inscrevem no cronotopo bolivariano porque contribuem, enquanto socialistas, para colocar em marcha uma democracia autêntica, pensada como um dos eixos do processo emancipatório. Em primeiro lugar, dois representantes do campo socialista, apesar de que ainda não se formulou o "socialismo do século XXI": Mao e Fidel. Isto mostra como esta primeira emissão vai esboçando os eixos políticos e as filiações que o legitimam: por um lado, como assinalamos antes, o patriotismo e, por outro, o vínculo ideológico com a tradição socialista. A fidelidade a uma e outra corrente se enlaçam no entramado ideológico da discursividade de Chávez. No seguinte encontro, a valorização da revolução chinesa se projeta como modelo para o processo venezuelano:

Dizia Mao Tse Tung, esse grande timoneiro da Revolução Chinesa, esse grande estrategista dizia, ouçam bem isto, amigos de toda a Venezuela. Dizia Mao: o povo está para o exército como a água para o peixe. Ontem, eu dizia aos generais, coroneis, comandantes e soldados, de lá, da brigada Zamora, rodeados de povo, porque as pessoas se metem entre a formação agora [...] Aquilo é lindo, menino!

A aliança do exército e do povo é fundamental no desenvolvimento dos objetivos de independência. Como esta não se concretizou porque ao império espanhol se sucederam outros, gerados pelo avanço capitalista, o exército venezuelano tem uma função a cumprir mas que somente pode se tornar efetiva com o apoio popular. "As pessoas que se metem na formação" é a imagem, muito comum nas revoluções democráticas, dessa aliança.

Também se convoca a voz autorizada de Fidel Castro, que exalta o nível de participação do povo venezuelano. Outra vez aparecem as metáforas que se constróem com elementos da natureza: “é um mar dizia Fidel Castro quando veio, e comentava comigo, este é um mar de gente, um mar de povo, no discurso que deu na Aula Magna da Universidade Central da Venezuela”. O marco em que se coloca a palavra de Fidel lhe atribui esta respeitabilidade e condição de julgamento fundamentado. A massividade dos atos públicos, que implica o reconhecimento popular, é um valor que deve ser ressaltado.

Finalmente, recupera a imagem de Cristo - em seu juramento do segundo mandato como presidente dirá "o maior socialista da história"- junto 
EID\&A - Revista Eletrônica de Estudos Integrados em Discurso e Argumentação, Ilhéus, n. 16 esp. "Discurso e argumentação na política latino-americana, set.2018.

à de Bolívar e ele se inscreve nessa série: "Eu estou inscrito nessa corrente de uma liderança autêntica que se enraíza em um compromisso indeclinável com os interesses do coletivo. É algo de Cristo, é algo de Bolívar também". A liderança autêntica se opõe às hierarquias formais. A humildade de Cristo, sua capacidade de compartilhar e sua aceitação do sacrifício pelo bem dos outros o fazem objeto da religiosidade popular constituindo-o em alguém próximo. Chávez se identifica com este olhar enquanto se posiciona, em diferentes momentos, no lugar daquele, já que transmite uma mensagem que se pensa como transcendente.

\section{Conclusão}

Encaramos a primeira emissão de Aló Presidente como aquela que expõe condensadamente a matriz da discursividade política de Chávez, que se estende não somente nas emissões posteriores mas também em outros cenários. Destacamos a representação que busca construir de um universo de iguais que (a partir do lugar de apresentador de uma emissão de rádio) a interlocução com os integrantes do programa e a audiência facilita. Marcamos a importância, no dispositivo enunciativo, da proximidade e da afetividade e da construção de um ethos de homem como os outros assim como de revolucionário. Esses traços facilitam os processos identificatórios, que fazem possível a mobilização do povo em torno das tarefas que as transformações empreendidas exigem. Colocamos como, em relação com o objetivo próximo, a Assembleia Constituinte designa ao que se enfrenta ao processo apelando energicamente aos mecanismos polarizadores da polêmica. Sublinhamos, do mesmo modo, o vínculo que estabelece com insistência entre o exército e o povo, como os dois pilares da revolução bolivariana, no que não se diferencia de outros desenvolvimentos semelhantes em países periféricos que devem lutar pela sua soberania ao mesmo tempo em que radicalizam a democracia. Finalmente, mostramos, nas filiações que ele estabelece, o entramado ideológico que sustenta a matriz discursiva, em que se atam a vontade de independência nacional, a exigência da participação popular nos processos políticos e a busca de uma sociedade mais justa para a qual a tradição socialista aparece como uma resposta primeira.

A partir desse complexo lugar ideológico e de uma matriz discursiva própria, Chávez construiu um poder político, que se manteve inclusive depois de sua morte. Por certo que as razões da eficácia dessa construção excedem o 
EID\&A - Revista Eletrônica de Estudos Integrados em Discurso e Argumentação, Ilhéus, n. 16 esp. "Discurso e argumentação na política latino-americana, set.2018.

plano da linguagem, ainda que seja este um instrumento de peso que foi questionado a partir de variadas posições teóricas. Talvez essas razões se assentem em algo mais geral: a necessidade que têm as amplas maiorias, para sua própria sobrevivência em condições dignas, de defender os recursos naturais de seu país e alcançar um desenvolvimento com certo grau de autonomia em uma situação internacional marcadamente desfavorável que Ihes impõe que se afirmem no aparato do Estado. No caso venezuelano, o discurso chavista Ihes permitiu tomar consciência disso, armar-se ideologicamente e participar intensamente da cena política.

\section{Fontes}

CHÁVEZ, Hugo Todo Chávez, Caracas: Ministerio del Poder Popular para la Comunicación y la Información, 2016. http://todochavezenlaweb.gob.ve/ Consultado $16 / 6 / 2017$.

\section{Referências}

AMOSSY, Ruth . La presentation de soi. Ethos et identité verbale. París: PUF, 2010.

Amossy, Ruth. Apologie de la polémique. París: PUF, 2014.

ARNOUX, Elvira N. El cronotopo bolivariano. In: latinoamericanista de Hugo Chávez. Buenos Aires, Ed. Biblos, 2008a.

- El discurso

ARNOUX, Elvira N. La construcción del objeto Nación Chilena en el Manual de Istoria de Chile de Vicente Fidel López. In: Los discursos sobre la nación y el lenguaje en la formación del Estado (Chile, 1842-1862). Estudio glotopolítico. Buenos Aires: Santiago Arcos, 2008b. p. 35-91.

ARNOUX, Elvira N. Las fronteras políticas: 'socialismo del siglo XXI' y capitalismo en la profundización del proceso venezolano. La Rivada. Investigaciones en Ciencias Sociales, Misiones, v. 1, n. 1, 2013.

ARNOUX, Elvira N. La dimensión didáctica en la construcción del 'socialismo del siglo XXI. In: __ _ Z ZACCARI, Verónica (Org.). Discurso y política en Sudamérica. Buenos Aires: Biblos, 2015. p.359-402.

BEAUGRANDE, Robert. The Discourse and CounterDiscourse of Hugo Chavez. Critical Approaches to Discourse Analysis across Disciplines, v. 2, n. 1, p.17-30, 2008. 
EID\&A - Revista Eletrônica de Estudos Integrados em Discurso e Argumentação, Ilhéus, n. 16 esp. "Discurso e argumentação na política latino-americana, set.2018.

BOLÍVAR, Adriana. Nuevos géneros discursivos en la política: el caso de Aló presidente. In: BERARDI, Leda (Comp.). Análisis Crítico del Discurso. Perspectivas latinoamericanas. Santiago de Chile: Frasis Editores, 2003.

CHARAUDEAU, Patrick. Le discours politique. Les masques du pouvoir. París: Vuibert, 2005.

CONSTANTINI, Sunthai. The Political Communication of Hugo Chávez: The Evolution of 'Alo Presidente. Tese (doutorado). Universidad de Kent, 2014.

DUARTE, Mercedes. Funciones estratégicas de las redes de metáforas en torno a 'socialismo': un análisis interaccional del discurso político de Hugo Chávez. Signos, v. 49 , n. $90,2016$.

ELRICH, Frances. Características y efectos del discurso autocentrado en Aló Presidente. Boletín de Lingüística, v. 17, n. 24, p.3-32, 2005 a.

- La relación interpersonal con la audiencia: el caso del discurso del presidente venezolano Hugo Chávez. Signos, v. 38, n. 59, p.287-302, 2005 b.

FOUCAULT, Michel. El gobierno de sí y de los otros. Buenos Aires: Fondo de Cultura Económica, 2009.

. El coraje de la verdad. Buenos Aires: Fondo de Cultura Económica, 2010.

GONZÁLEZ BINETTI, María Fernanda. Hugo Chávez et Álvaro Uribe ou la force des mots. París: L'Harmattan, 2012.

GRIZE, Jean-Blaise. Le point de vue de la logique naturelle: demontrer, prouver, argumenter. In: DOURY, Marianne; MOIRAND, Sophie (Ed.). L'argumentation aujourd'hui. París: Presses Sorbonne Nouvelle, 2004. p.35-44.

MAINGUENEAU, Dominique . Les phrases sans texte. París: Armand Colin, 2012.

MICHELI, Raphaël. Les émotions dans les discours. Lovaina: De Boeck \& Duculot, 2014.

NIETO Y OTERO, María Jesús. Comunicación afectiva en el discurso político venezolano. Estudio del pronombre pseudoinclusivo 'nosotros'. Spanish in context, v.1, n.2, p. 267-284, 2004.

PEÑAFIEL, Ricardo. L'image du peuple. Construction de l'ethos plébéien de Hugo Chávez dans l'émission Aló Presidente. Mots, n. 96, p.29-44, 2011.

PLANTIN, Christian. Ethos. Dictionnaire de l’argumentation. Lyon, ENS Éditions, 2016.

RAMÍREZ LASSO, Lilia M. Géneros y funciones en Aló Presidente: un género complejo. Revista de Ciencias Sociales, v. XVIII, n. 4, p.613-627, 2012. 
EID\&A - Revista Eletrônica de Estudos Integrados em Discurso e Argumentação, Ilhéus, n. 16 esp. "Discurso e argumentação na política latino-americana, set.2018.

. Identidades colectivas en el discurso político-mediático venezolano: el Aló Presidente y la representación de la sociedad venezolana". Romanica Olomucensia, v.27, n.1, p. 81-99, 2015.

ROSA GUALDA, Ricardo José. The Discourse of Hugo Chávez in 'Aló Presidente': Establishing the Bolivarian Revolution through Television Performance. Tese (Doutorado). Universidade do Texas, 2012.

SMITH, Dominic N. A. A Corpus-Driven Discourse. Analysis of Transcripts of Hugo Chávez Television Programme 'Aló Presidente'. Tese (doutorado). Universidade de Birmingham, 2010.

Tradução:

Maysa Ramos

Doutoranda do Programa de Pós-Graduação em Linguística da Universidade Federal de São Carlos (UFSCar)

Forma de citação sugerida:

ARNOUX, Elvira Narvaja de. Esboço de uma política comunicacional e exposição de uma matriz discursiva: a primeira veiculação de Aló Presidente (Hugo Chávez, 1999). Trad. Maysa Ramos. EID\&A - Revista Eletrônica de Estudos Integrados em Discurso e Argumentação, Ilhéus, n. 16 esp. "Discurso e argumentação na política latinoamericana", p. 71-102, set.2018. 